Supporting Information

\title{
Elucidating Roles of Polymer Donor Aggregation in All-Polymer and Non-Fullerene Small Molecule-Polymer Solar Cells
}

Jin Su Park, ${ }^{\dagger, \dagger}$ Nayoun Choi, ${ }^{\dagger}, \dot{\dagger}$ Changyeon Lee ${ }^{\dagger}$, Seungjin Lee, ${ }^{\dagger}$ Jong-Woon Ha, ${ }^{\S}$ Do-Hoon Hwang, ${ }^{*}$, and Bumjoon J. Kim ${ }^{*} \dagger$

${ }^{\dagger}$ Department of Chemical and Biomolecular Engineering, Korea Advanced Institute of Science and Technology (KAIST), Daejeon 34141, Republic of Korea

${ }^{\S}$ Department of Chemistry and Chemistry Institute for Functional Materials, Pusan National University, Busan 46241, Republic of Korea

*(B. J. Kim) E-mail: bumjoonkim @kaist.ac.kr

*(D.-H. Hwang) E-mail: dohoonhwang@pusan.ac.kr 


\section{Table of Contents}

\section{Experimental Section}

\section{Supplementary Scheme S1}

- Scheme S1. Synthetic routes of monomers and polymers

\section{Supplementary Figure S1 - S8}

- Figure S1. ${ }^{1} \mathrm{H}$ NMR spectra of synthesized monomers.

- Figure S2. CV curves of pristine films of (a) $P_{\mathrm{DS}}$ and (b) acceptor materials.

- Figure S3. (a) TGA curves and (b) second cycle heating DSC curves of $P_{\mathrm{DS}}$.

- Figure S4. Absorption coefficients of pristine films of $P_{\mathrm{D}}$ and acceptors prepared from (a) chlorobenzene solution and (b) chloroform solution. Absorption coefficients of (c) $P_{\mathrm{D}}: \mathrm{P}(\mathrm{NDI} 2 \mathrm{OD}-\mathrm{T} 2)$ and (d) $P_{\mathrm{D}}$ :Y6 blend films at the optimized device condition.

- Figure S5. Dependence of $J_{s c}$ on light intensity of (a) $P_{\mathrm{D}}: \mathrm{P}(\mathrm{NDI} 2 \mathrm{OD}-\mathrm{T} 2)$ and (b) $P_{\mathrm{D}}$ :Y6-based PSCs.

- Figure S6. Photocurrent analysis of (a) $P_{\mathrm{D}}: \mathrm{P}(\mathrm{NDI} 2 \mathrm{OD}-\mathrm{T} 2)$ and (b) $P_{\mathrm{D}}$ :Y6-based PSCs.

- Figure S7. AFM height images measured with pristine films of (a) P-EH, (b) P-SEH, and (c) P-Si.

- Figure S8. (a) GIXS patterns of all-PSC blend films. (b) In-plane $\left(q_{x y}\right)$ and out-ofplane $\left(q_{z}\right)$ linecuts of GIXS patterns of all-PSC blend films. (c) GIXS patterns of NFSMA-PSC blend films. (d) In-plane $\left(q_{x y}\right)$ and out-of-plane $\left(q_{z}\right)$ linecuts of GIXS patterns of NFSMA-PSC blend films.

\section{Supplementary Table S1 - S5}

- Table S1. Stille conditions for P-EH and polymerization results.

- Table S2. Stille conditions for P-SEH and polymerization results.

- Table S3. Stille conditions for P-Si and polymerization results.

- Table S4. SCLC hole and electron mobilities of all-PSC and NFSMA-PSC blend Films.

- Table S5. Contact angles and surface tensions of $P_{\mathrm{DS}}$ (P-EH, P-SEH, and P-Si), $\mathrm{P}(\mathrm{NDI} 2 \mathrm{OD}-\mathrm{T} 2)$, and $\mathrm{Y} 6$ films measured with water and glycerol. Estimated interfacial tensions between $P_{\mathrm{DS}}$ and acceptors (P(NDI2OD-T2) and Y6).

\section{References}




\section{Experimental Section}

Materials. The ttTPD monomer was synthesized via modified process of the reference paper. 2,2'-((2Z,2'Z)-((12,13-bis(2-ethylhexyl)-3,9-diundecyl-12,13-dihydro-[1,2,5]thiadiazolo[3,4e] thieno[2",3'':4',5'] thieno[2',3':4,5]pyrrolo[3,2-g]thieno[2',3':4,5] thieno[3,2-b]indole-2,10-di yl)bis(methanylylidene))bis(5,6-difluoro-3-oxo-2,3-dihydro- $1 H$-indene-2,1-diylidene))dimalo n o nitrile (Y6) acceptor and 4,8-bis(5-(2-ethylhexyl)thiophen-2-yl)benzo[1,2-b:4,5$b^{\prime}$ ]dithiophene-2,6-diyl)bis(trimethylstannane) (BDT-EH) monomer were purchased from 1Materials and Sunatech Incorporation, respectively, and used without further purification. All other chemical reagents were purchased from Sigma Aldrich Co., Alfa Aesar, and Tokyo Chemical Industry Co. and used without further purification. Poly $\left\{\left[N, N^{\prime}\right.\right.$-bis(2-octyldodecyl)naphthalene-1,4,5,8-bis(dicarboximide)-2,6-diyl]-alt-5,5'-(2,2'-bithiophene)\} (P(NDI2ODT2)) and thienothiophene $\pi$-bridged $N$-alkylthieno[3,4-c]pyrrole-4,6-dione (ttTPD) monomer were synthesized by modified process of previously reported procedures. ${ }^{1,2}$ Clevios P VP AI 4083 was purchased from Heraeus (Germany) and used as PEDOT:PSS solution. The synthetic routes and detailed reaction procedures for monomers and $P_{\mathrm{DS}}$ are described below: 


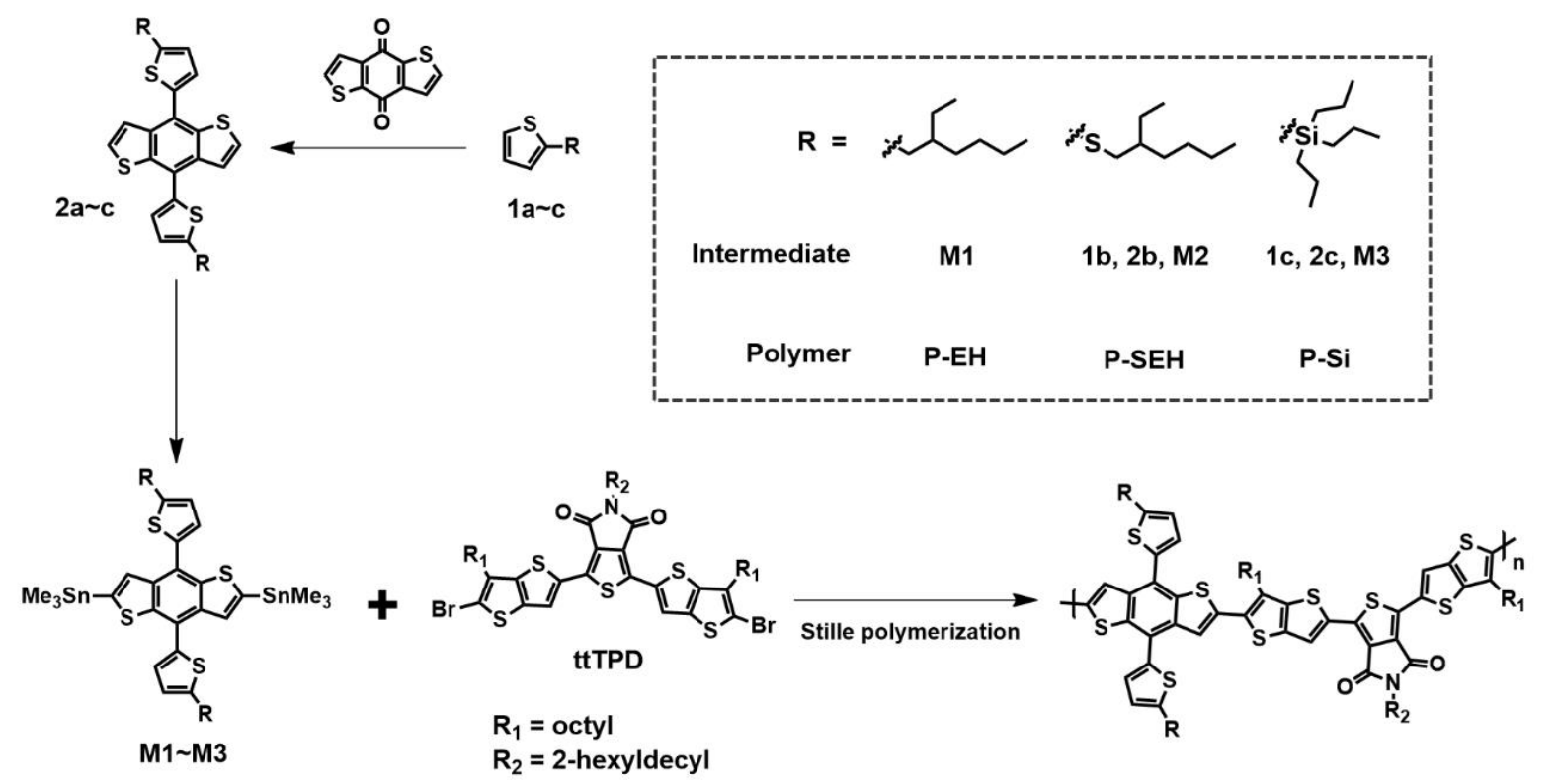

Scheme S1. Synthetic routes of monomers and polymers

Synthesis of 2-((2-ethylhexyl)thio)thiophene (1b). Under inert gas condition, 2bromothiophene (3.26 g, $20 \mathrm{mmol}$ ) was dissolved in dry tetrahydrofuran (THF, $20 \mathrm{~mL}$ ), and the solution was cooled to $0{ }^{\circ} \mathrm{C}$. To this, $\mathrm{n}$-BuLi solution $(2.5 \mathrm{M}$ in hexane, $8.4 \mathrm{~mL})$ was added dropwise, and the solution was kept stirring for $1 \mathrm{hr}$ at $0{ }^{\circ} \mathrm{C}$. Sulfur powder $(670 \mathrm{mg}, 21 \mathrm{mmol})$ was added in one portion, and the resulting suspension was stirred at $0{ }^{\circ} \mathrm{C}$ for $2 \mathrm{hr}$. To this, 2ethylhexylbromide (4.06 g, $21 \mathrm{mmol}$ ) was added dropwise and the reaction mixture was stirred overnight at room temperature. Then, ice water saturated with $\mathrm{NH}_{4} \mathrm{Cl}$ was added to the reaction. The crude mixture was extracted with diethyl ether, and washed with water and brine. The organic layer was dried over anhydrous $\mathrm{MgSO}_{4}$ and concentrated by rotary evaporator. Further purification was performed by column chromatography with hexane as the eluent to yield compound $\mathbf{1 b}$ (4.1 g, yield 90\%) as colorless oil. ${ }^{1} \mathrm{H}$ NMR (400 MHz, $\left.\mathrm{CDCl}_{3}\right), \delta$ (ppm): 7.30$7.28(\mathrm{~m}, 1 \mathrm{H}), 7.08-7.06(\mathrm{~m}, 1 \mathrm{H}), 6.95-6.92(\mathrm{~m}, 1 \mathrm{H}), 2.82-2.78(\mathrm{~d}, 2 \mathrm{H}), 1.53-1.17(\mathrm{~m}, 8 \mathrm{H})$, $0.91-0.82(\mathrm{~m}, 6 \mathrm{H}) . \mathrm{MS}: m / z=228$. 
Synthesis of tripropyl(thiophene-2-yl)silane (1c). Under inert gas condition, 2bromothiophene (1.8 g, $10.9 \mathrm{mmol})$ was dissolved in dry THF $(15 \mathrm{~mL})$, and the solution was cooled to $-78{ }^{\circ} \mathrm{C}$. To this, $\mathrm{n}$-BuLi solution $(2.5 \mathrm{M}$ in hexane, $4.57 \mathrm{~mL})$ was added dropwise, and the solution was kept stirring for $1 \mathrm{hr}$ at $-78{ }^{\circ} \mathrm{C}$. Then, chlorotripropylsilane $(2.205 \mathrm{~g}, 11.4$ mmol) was added dropwise. The solution was kept at $-78^{\circ} \mathrm{C}$ for $15 \mathrm{~min}$. Then, the solution was warmed slowly to room temperature and stirred overnight. Water was poured to quench the reaction. The crude mixture was extracted with diethyl ether, and washed by water and brine. The organic layer was dried over anhydrous $\mathrm{MgSO}_{4}$ and concentrated by rotary evaporator. Further purification was performed by column chromatography with hexane as the eluent to yield compound $1 \mathrm{c}(1.7 \mathrm{~g}$, yield $64 \%)$ as a yellow oil product. ${ }^{1} \mathrm{H} \mathrm{NMR}\left(400 \mathrm{MHz}, \mathrm{CDCl}_{3}\right), \delta$ (ppm): 7.60-7.58 (d, 1H), 7.25-7.24 (d, 1H), 7.20-7.17 (m, 1H), 1.46-1.32 (m, 6H), 0.99-0.94 $(\mathrm{m}, 9 \mathrm{H}), 0.83-0.77(\mathrm{~m}, 6 \mathrm{H}) . \mathrm{MS}: m / z=240$.

\section{Synthesis of 4,8-bis(5-((2-ethylhexyl)thio)thiophen-2-yl)benzo[1,2-b:4,5- $b$ ']dithiophene}

(2b). Under inert gas condition, $\mathbf{1 b}(3 \mathrm{~g}, 13.1 \mathrm{mmol})$ was dissolved in dry THF (30 mL), and the solution was cooled to $-78{ }^{\circ} \mathrm{C}$. To this, $\mathrm{n}$-BuLi solution $(2.5 \mathrm{M}$ in hexane, $5.5 \mathrm{~mL})$ was added dropwise, and the solution was warmed to $50{ }^{\circ} \mathrm{C}$ and kept stirring for $30 \mathrm{~min}$. Subsequently, benzo[1,2- $\left.b: 4,5-b^{`}\right]$ dithiophene-4,8-dione (0.96 g, $\left.4.3 \mathrm{mmol}\right)$ was added and stirred for $1 \mathrm{hr}$. Then, the solution was cooled to room temperature and a solution of $\mathrm{SnCl}_{2} \cdot 2 \mathrm{H}_{2} \mathrm{O}$ in $10 \% \mathrm{HCl}$ was added. The reaction mixture was stirred for another $2 \mathrm{hr}$, and poured into ice water and extracted with diethyl ether. The organic layer was washed with brine, dried over $\mathrm{MgSO}_{4}$, and concentrated by rotary evaporator. Further purification was performed with column chromatography with chloroform/hexane (v/v: 2:8) as the eluent to yield pure compound $2 \mathbf{b}(1.7 \mathrm{~g}$, yield $61 \%)$ as a yellow crystal product. ${ }^{1} \mathrm{H}$ NMR $\left(400 \mathrm{MHz}, \mathrm{CDCl}_{3}\right), \delta$ (ppm): 7.60-7.58 (d, 2H), 7.46-7.45 (d, 2H), 7.31-7.30 (d, 2H), 7.20-7.19 (d, 2H), 2.93-2.91 (d, 
4H), 1.65-1.58 (m, 2H), 1.53-1.24 (m, 16H), 0.91-0.87 (t, 12H). MALDI-TOF MS: calcd for $\mathrm{C}_{34} \mathrm{H}_{42} \mathrm{~S}_{6} \mathrm{~m} / \mathrm{z}=643.09$; found 642.3.

\section{Synthesis of 4,8-bis(5-(tripropylsilyl)thiophen-2-yl)benzo[1,2-b:4,5- $\left.b^{\prime}\right]$ dithiophene (2c).} Under inert gas condition, 1c $(2.41 \mathrm{~g}, 10 \mathrm{mmol})$ was dissolved in dry THF $(30 \mathrm{~mL})$, and the solution was cooled to $0{ }^{\circ} \mathrm{C}$. To this, $\mathrm{n}-\mathrm{BuLi}$ solution $(2.5 \mathrm{M}$ in hexane, $4.0 \mathrm{~mL})$ was added dropwise, and the solution was kept at $0{ }^{\circ} \mathrm{C}$ for $15 \mathrm{~min}$. Then, the solution was warmed to $50{ }^{\circ} \mathrm{C}$ and kept stirring for $2 \mathrm{hr}$. Subsequently, benzo[1,2-b:4,5- $\left.b^{`}\right]$ dithiophene-4,8-dione (740 mg, $3.36 \mathrm{mmol}$ ) was added and stirred for $2 \mathrm{hr}$. Then, the solution was cooled to $0{ }^{\circ} \mathrm{C}$ and a solution of $\mathrm{SnCl}_{2} \cdot 2 \mathrm{H}_{2} \mathrm{O}(4.5 \mathrm{~g}, 20 \mathrm{mmol})$ in $10 \% \mathrm{HCl}$ was added. The solution was warmed to room temperature and stirred for another $30 \mathrm{~min}$. Then, the reaction mixture was poured into ice water and extracted with diethyl ether. The organic layer was washed with brine, dried over anhydrous $\mathrm{MgSO}_{4}$, and concentrated by rotary evaporator. Rough purification was performed with column chromatography with chloroform/hexane (v/v: 2:8) as the eluent to yield a yellow crystal mixture including compound $\mathbf{2 c}$ as a major product. The resulting mixture was used for further reaction.

\section{Synthesis of 4,8-bis(5-((2-ethylhexyl)thio)thiophen-2-yl)benzo[1,2-b:4,5- $b$ ']dithiophene-} 2,6-diyl)bis(trimethylstannane) (M2). Under inert gas condition, $2 \mathbf{b}$ (1.7 g, $2.6 \mathrm{mmol})$ was dissolved in dry THF, and the solution was cooled to $-78^{\circ} \mathrm{C}$. To this, n-BuLi solution $(2.5 \mathrm{M}$ in hexane, $2.4 \mathrm{~mL}$ ) was added dropwise and kept stirring for $1 \mathrm{hr}$. Then, trimethyltin chloride solution (1.0 M in THF, $6.9 \mathrm{~mL}$ ) was added in one portion. The reaction mixture was stirred at $-78^{\circ} \mathrm{C}$ for $15 \mathrm{~min}$ and the cooling bath was removed. After stirred overnight, the mixture was poured into water and extracted by diethyl ether. The organic layer was washed with brine, dried over $\mathrm{MgSO}_{4}$, and concentrated by rotary evaporator. The crude compound was further 
purified by recrystallization with methanol to yield M2 monomer (1.49 g, yield 58\%) as a lightyellow solid. ${ }^{1} \mathrm{H}$ NMR (400 MHz, $\mathrm{CDCl}_{3}$ ), $\delta(\mathrm{ppm}): 8.62(\mathrm{~s}, 2 \mathrm{H}), 7.33-7.32(\mathrm{~d}, 2 \mathrm{H}), 7.21-7.20$ $(\mathrm{d}, 2 \mathrm{H}), 2.93-2.91(\mathrm{~d}, 4 \mathrm{H}), 1.68-1.60(\mathrm{~m}, 2 \mathrm{H}), 1.51-1.25(\mathrm{~m}, 16 \mathrm{H}), 0.90-0.86(\mathrm{~m}, 12 \mathrm{H}), 0.48-$ $0.29(\mathrm{t}, 18 \mathrm{H})$. MALDI-TOF MS: calcd for $\mathrm{C}_{40} \mathrm{H}_{58} \mathrm{~S}_{6} \mathrm{Sn}_{2} \mathrm{~m} / \mathrm{z}=968.70$; found 968.5.

Synthesis of $\quad 5,5^{\prime}-\left(2,6-b i s(t r i m e t h y l s t a n n y l) b e n z o\left[1,2-b: 4,5-b^{\prime}\right]\right.$ dithiophene-4,8diyl)bis(thiophene-5,2-diyl)bis(tripropylsilane) (M3). M3 monomer was synthesized similarly as described above for $\mathbf{M} 2$ except that compound $\mathbf{2 c}(2 \mathrm{~g}, 3.0 \mathrm{mmol})$ was used instead of $\mathbf{2 b}\left(1.82 \mathrm{~g}\right.$, yield 61\%). ${ }^{1} \mathrm{H}$ NMR (400 MHz, $\left.\mathrm{CDCl}_{3}\right), \delta(\mathrm{ppm}): 7.73-7.66(\mathrm{t}, 2 \mathrm{H}), 7.59-7.58$ $(\mathrm{d}, 2 \mathrm{H}), 7.35-7.34(\mathrm{~d}, 2 \mathrm{H}), 1.52-1.42(\mathrm{~m}, 12 \mathrm{H}), 1.03-0.98(\mathrm{~m}, 18 \mathrm{H}), 0.89-0.84(\mathrm{~m}, 12 \mathrm{H}), 0.45-$ $0.30(\mathrm{t}, 18 \mathrm{H})$. MALDI-TOF MS: calcd for $\mathrm{C}_{42} \mathrm{H}_{66} \mathrm{~S}_{4} \mathrm{Si}_{2} \mathrm{Sn}_{2} \mathrm{~m} / z=992.82$; found 992.4.

Polymerization. $P_{\mathrm{DS}}$ were synthesized via Stille polycondensation of distannylated BDT and dibrominated ttTPD monomers. The detailed reaction conditions used for each trial are summarized in Table S1 - S3. Monomers, catalysts, and ligands (if needed) were placed in a round-bottom flask under argon. Dry solvents were added and the mixture was treated with bubbling for $5 \mathrm{~min}$. Then, the solution was heated to $110^{\circ} \mathrm{C}$ and stirred vigorously for specific reaction time. After cooling to room temperature, the solution was precipitated into methanol $(300 \mathrm{~mL})$. The precipitated polymers were purified by sequential Soxhlet extraction with methanol, acetone, hexane, dichloromethane, and chloroform. The chloroform fraction was precipitated into methanol $(200 \mathrm{~mL})$, isolated by filtration, and dried under vacuum at $40{ }^{\circ} \mathrm{C}$ for $24 \mathrm{hr}$ to yield the desired $P_{\mathrm{D}}$.

Space-charge-limited current (SCLC) measurements. Hole and electron mobilities of all pristine and blend films were measured by SCLC method using device structures of indium tin 
oxide

(PEDOT:PSS)/polymer blends/Au (hole-only) and ITO/ZnO/polymer blends/poly[(9,9-bis(3'(N,N-dimethylamino)propyl)-2,7-fluorene)-alt-2,7-(9,9-dioctylfluorene)] (PFN)/Al (electrononly). The blend films were prepared as optimized for devices. A range of $0-8 \mathrm{~V}$ was applied for the current-voltage measurements, and the results were fitted to the Mott-Gurney equation:

$$
J_{S C L C}=\frac{9}{8} \varepsilon \varepsilon_{0} \mu \frac{V^{2}}{L^{3}}
$$

where $\varepsilon_{0}$ is the permittivity of free space $\left(8.85 \times 10^{-14} \mathrm{~F} \mathrm{~cm}^{-1}\right), \varepsilon$ is the relative dielectric constant of the active layer, $\mu$ is the charge carrier mobility, $V$ is the potential across the device $(V=$ $V_{\text {applied }}-V_{\mathrm{bi}}-V_{\mathrm{r}}$, where $V_{\mathrm{bi}}$ is the built-in potential and $V_{\mathrm{r}}$ is the voltage drop caused by the resistance), and $L$ is the thickness of the blend film. 
Supplementary Figures \& Tables
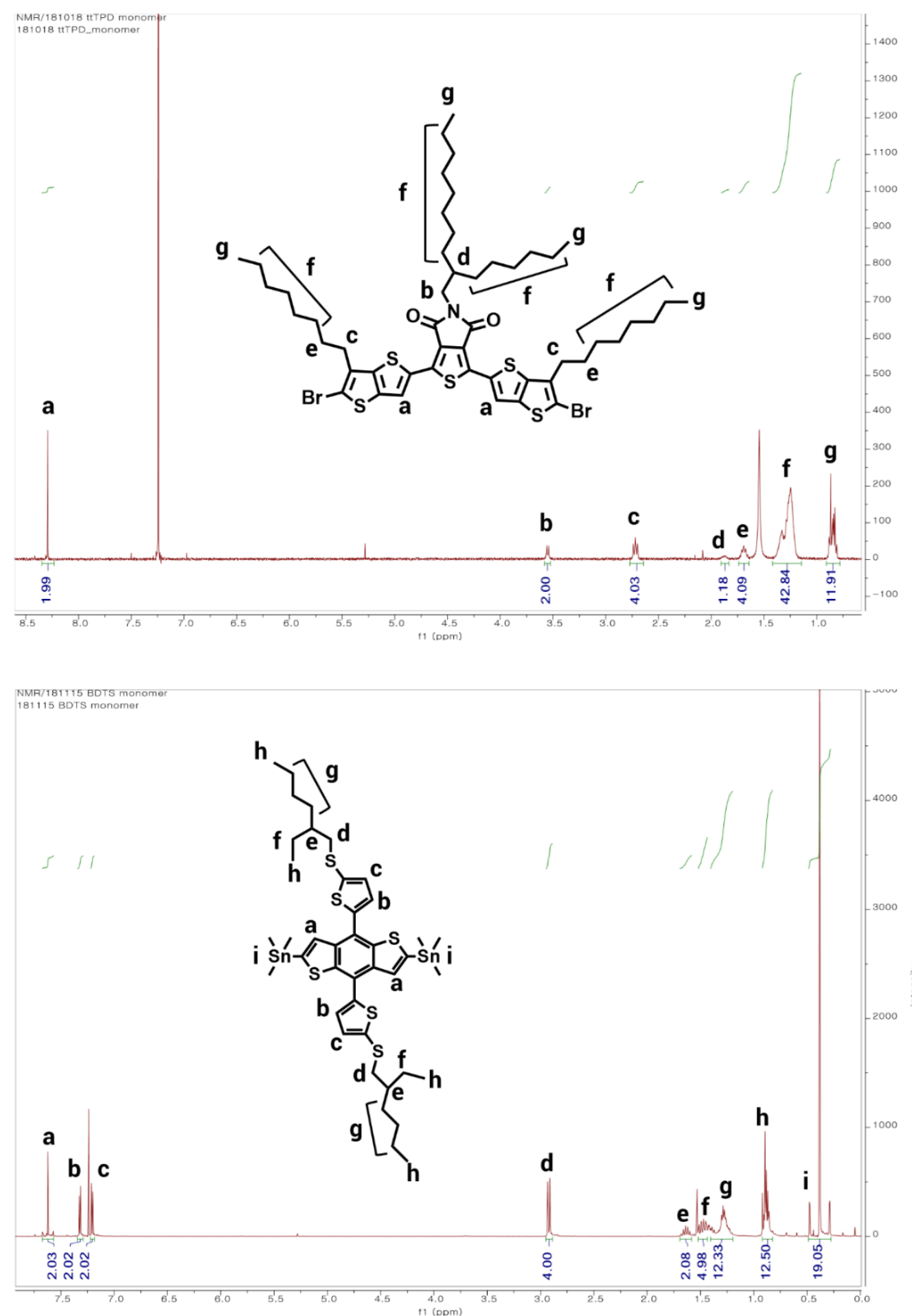


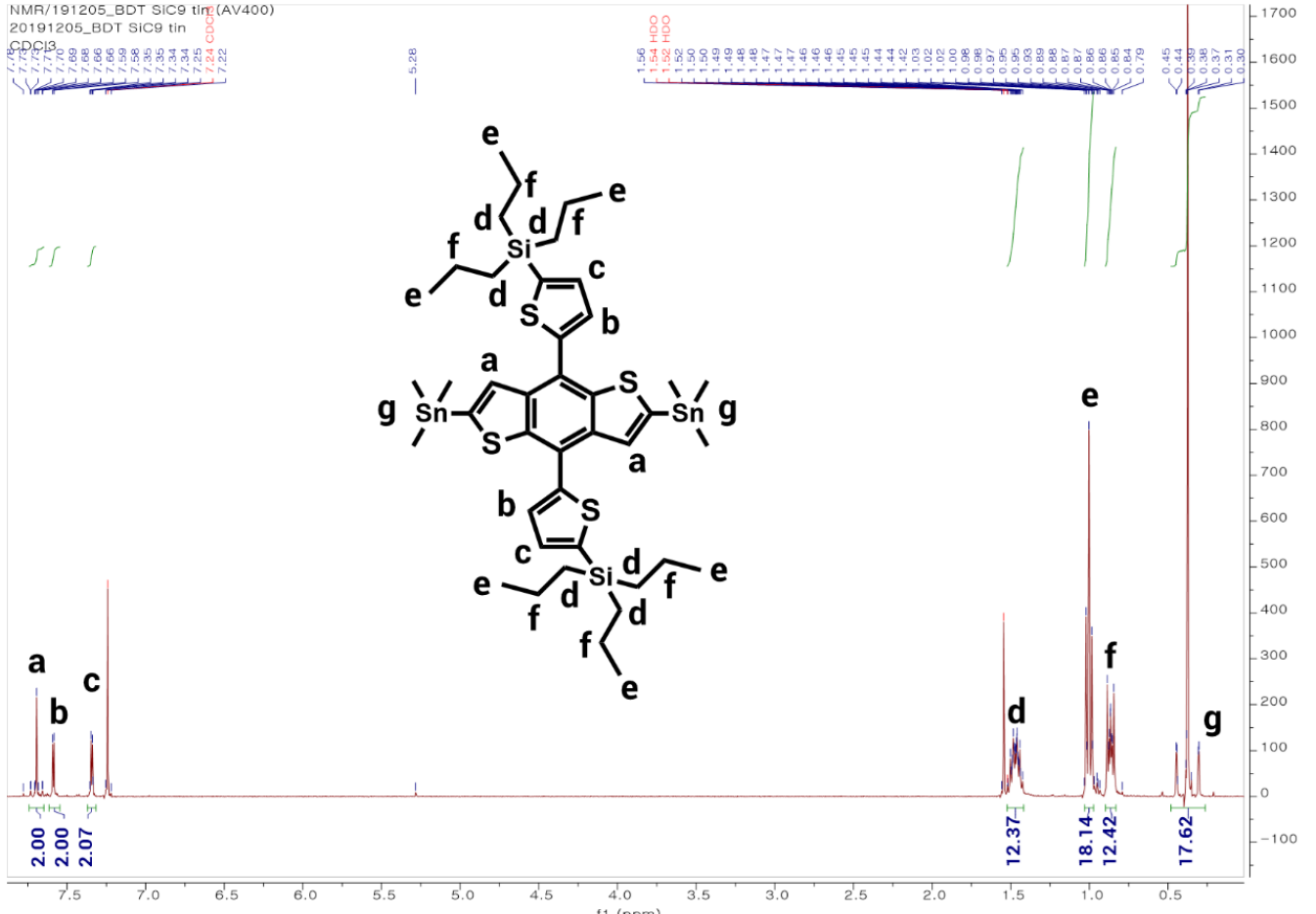

Figure S1. ${ }^{1} \mathrm{H}$ NMR spectra of synthesized monomers. 
Table S1. Stille conditions for P-EH and polymerization results.

\begin{tabular}{ccccccc}
\hline Batch \# & $\begin{array}{c}\text { Solvent }^{\mathrm{a}} \\
(\mathrm{mL})\end{array}$ & Catalyst & $\begin{array}{c}\text { Reaction time } \\
(\mathrm{hr})\end{array}$ & $\begin{array}{c}M_{\mathrm{n}}^{\mathrm{b}} \\
\left(\mathrm{kg} \mathrm{mol}^{-1}\right)\end{array}$ & $\Xi^{\mathrm{b}}$ & $\begin{array}{c}\text { Yield }^{\mathrm{c}} \\
(\%)\end{array}$ \\
\hline P-EH 1 & & & 14 & 27 & 3.9 & $<5$ \\
2 & & 2 & 48 & 5.5 & 75 \\
3 & Tol / DMF & $\mathrm{Pd}\left(\mathrm{PPh}_{3}\right)_{4}$ & 4 & $\mathrm{NY}^{\mathrm{e}}$ & $\mathrm{NY}^{\mathrm{e}}$ & $\mathrm{NY}^{\mathrm{e}}$ \\
4 & $5: 1$ & $1 \mathrm{~mol}_{0}$ & $2+12^{\mathrm{d}}$ & $\mathrm{NY}^{\mathrm{e}}$ & $\mathrm{NY}^{\mathrm{e}}$ & $\mathrm{NY}^{\mathrm{e}}$ \\
5 & & & 2 & 42 & 3.7 & 25 \\
6 & & & 3 & 37 & 3.8 & 75 \\
\hline
\end{tabular}

${ }^{\mathrm{a}}$ All polymerizations were conducted with $0.03 \mathrm{M}$ concentration. ${ }^{\mathrm{b}} \mathrm{The} M_{\mathrm{n}}$ and $\oslash$ of the polymers were determined by SEC using $o$-DCB as the eluent at $80{ }^{\circ} \mathrm{C}$. ${ }^{\mathrm{c}}$ Determined after purification via Soxhlet extraction. ${ }^{\mathrm{d}}$ After $2 \mathrm{hr}$ of reaction, $5 \%$ of end-capping reagent i.e. 2-bromothiophene was added to the reacting solution and the reaction went for additional $12 \mathrm{hr}$. ${ }^{\mathrm{e}} \mathrm{NY}$ indicates no yield due to either no polymer formation or yield of insoluble polymer batch.

Table S2. Stille conditions for P-SEH and polymerization results.

\begin{tabular}{ccccccc}
\hline Batch \# & $\begin{array}{c}\text { Solvent } \\
(\mathrm{mL})\end{array}$ & Catalyst & $\begin{array}{c}\text { Reaction time } \\
(\mathrm{hr})\end{array}$ & $\begin{array}{c}M_{\mathrm{n}}^{\mathrm{b}} \\
\left(\mathrm{kg} \mathrm{mol}^{-1}\right)\end{array}$ & $\Xi^{\mathrm{b}}$ & $\begin{array}{c}\text { Yield }^{\mathrm{c}} \\
(\%)\end{array}$ \\
\hline P-SEH 1 & Tol / DMF 5:1 & & 2 & $\mathrm{NY}^{\mathrm{d}}$ & $\mathrm{NY}^{\mathrm{d}}$ & $\mathrm{NY}^{\mathrm{d}}$ \\
2 & Tol / DMF 5:1 & & 1.5 & 16 & 4.2 & 32 \\
3 & Tol & ${\mathrm{Pd}\left(\mathrm{PPh}_{3}\right)_{4}}^{\mathrm{d}}$ & 14 & 23 & 5.1 & 13 \\
4 & Tol & 10 & 23 & 3.7 & 26 \\
5 & $\mathrm{CB}$ & & 24 & 27 & 3.3 & $<5$ \\
6 & Tol & & 8 & 28 & 4.3 & 22 \\
7 & Tol & & 6 & 33 & 5.5 & 70 \\
\hline
\end{tabular}

${ }^{\mathrm{a} A l l}$ polymerizations were conducted with $0.03 \mathrm{M}$ concentration. ${ }^{\mathrm{b}} \mathrm{The} M_{\mathrm{n}}$ and $\doteq$ of the polymers were determined by SEC using $o$-DCB as an eluent at $80{ }^{\circ} \mathrm{C}$. ${ }^{\mathrm{c}}$ Determined after purification via Soxhlet extraction. ${ }^{\mathrm{d}} \mathrm{NY}$ indicates no yield due to either no polymer formation or yield of insoluble polymer batch. 
Table S3. Stille conditions for P-Si and polymerization results.

\begin{tabular}{|c|c|c|c|c|c|c|}
\hline Batch \# & $\begin{array}{l}\text { Solvent }^{\mathrm{a}} \\
(\mathrm{mL})\end{array}$ & $\begin{array}{l}\text { Catalyst } \\
(\mathrm{mol} \%)\end{array}$ & $\begin{array}{l}\text { Reaction time } \\
\text { (hr) }\end{array}$ & $\begin{array}{c}M_{\mathrm{n}}^{\mathrm{b}} \\
\left(\mathrm{kg} \mathrm{mol}^{-1}\right)\end{array}$ & $\bigoplus^{\mathrm{b}}$ & $\begin{array}{c}\text { Yield }^{\mathrm{c}} \\
(\%)\end{array}$ \\
\hline P-Si 1 & Tol / DMF 5:1 & $\mathrm{Pd}\left(\mathrm{PPh}_{3}\right)_{4}(1)$ & 24 & 16 & 2.4 & $<5$ \\
\hline 2 & Tol & $\mathrm{Pd}\left(\mathrm{PPh}_{3}\right)_{4}(1)$ & 24 & 21 & 2.0 & $<5$ \\
\hline 3 & $\mathrm{CB}$ & $\mathrm{Pd}\left(\mathrm{PPh}_{3}\right)_{4}(1)$ & 24 & $N Y^{d}$ & $N Y^{d}$ & $N Y^{d}$ \\
\hline 4 & Tol / DMF 5:1 & $\mathrm{Pd}\left(\mathrm{PPh}_{3}\right)_{4}(1)$ & 36 & 22 & 2.3 & 32 \\
\hline 5 & Tol / DMF 5:1 & $\mathrm{Pd}\left(\mathrm{PPh}_{3}\right)_{4}(2+1)^{\mathrm{e}}$ & $48+48$ & 24 & 2.3 & 45 \\
\hline 6 & Tol / DMF 5:1 & $\mathrm{Pd}_{2}(\mathrm{dba})_{3}(2+2)^{\mathrm{e}}$ & $48+48$ & 23 & 2.2 & 74 \\
\hline 7 & Tol / DMF 5:1 & $\mathrm{Pd}_{2}(\mathrm{dba})_{3}(2)$ & $6^{\mathrm{f}}$ & 21 & 2.1 & 51 \\
\hline
\end{tabular}

${ }^{\mathrm{a}}$ All polymerizations were conducted with $0.03 \mathrm{M}$ concentration. ${ }^{\mathrm{b}} \mathrm{The} M_{\mathrm{n}}$ and $\oslash$ of the polymers were determined by SEC using $o$-DCB as an eluent at $80{ }^{\circ} \mathrm{C}$. ${ }^{c}$ Determined after purification via Soxhlet extraction. ${ }^{\mathrm{d}} \mathrm{NY}$ indicates no yield due to either no polymer formation or yield of insoluble polymer batch. ${ }^{\mathrm{e}} \mathrm{After} 48 \mathrm{hr}$ of reaction, additional catalyst was added to the reaction solution, and the reaction was kept for another $48 \mathrm{hr}$. ${ }^{\mathrm{f}}$ The reaction was proceeded in microwave reactor.
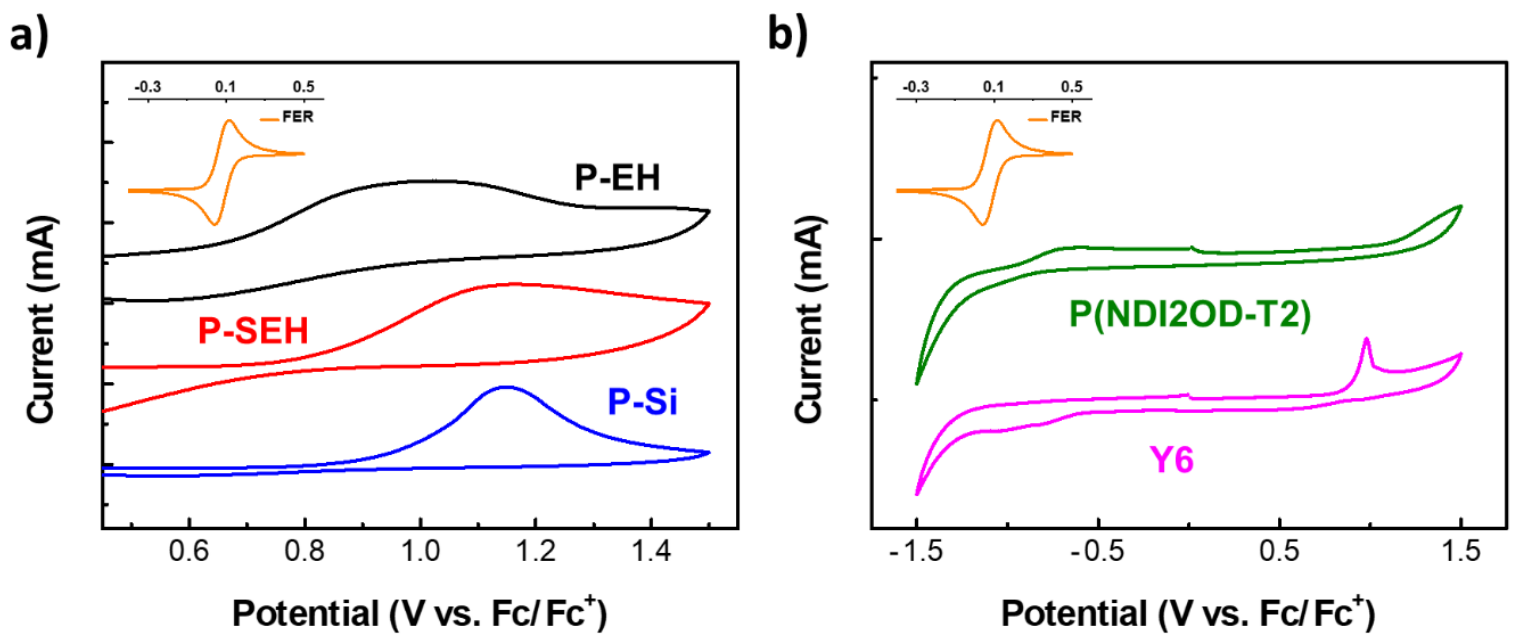

Figure S2. CV curves of pristine films of (a) $P_{\mathrm{DS}}$ and (b) acceptor materials. 
a)

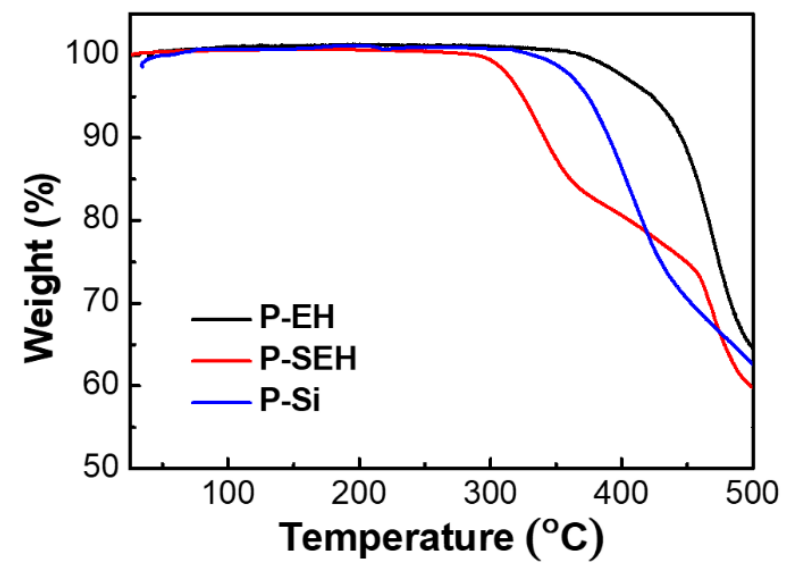

b)

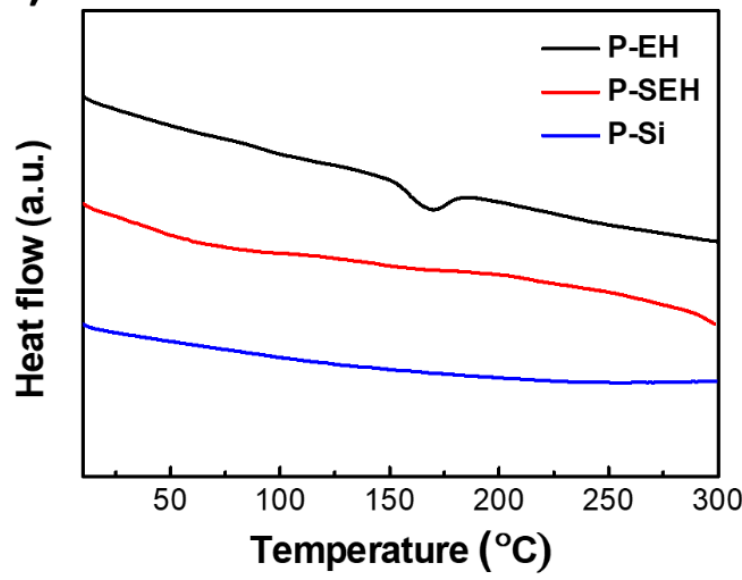

Figure S3. (a) TGA curves and (b) second cycle heating DSC curves of $P_{\mathrm{DS}}$.

a)

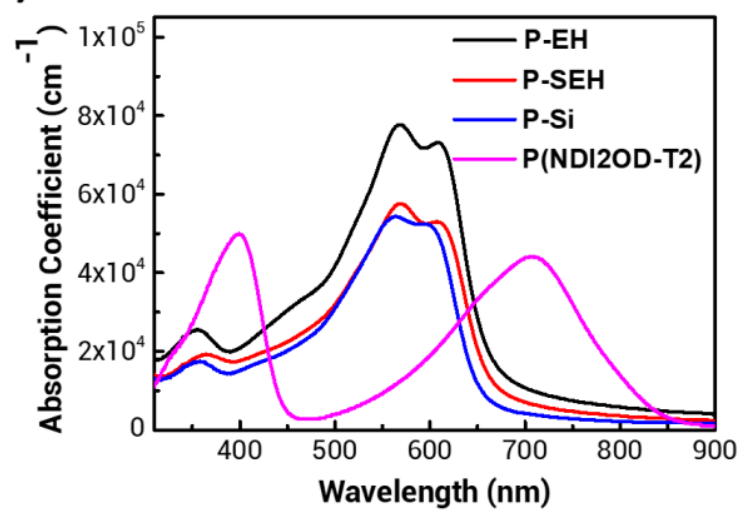

c)

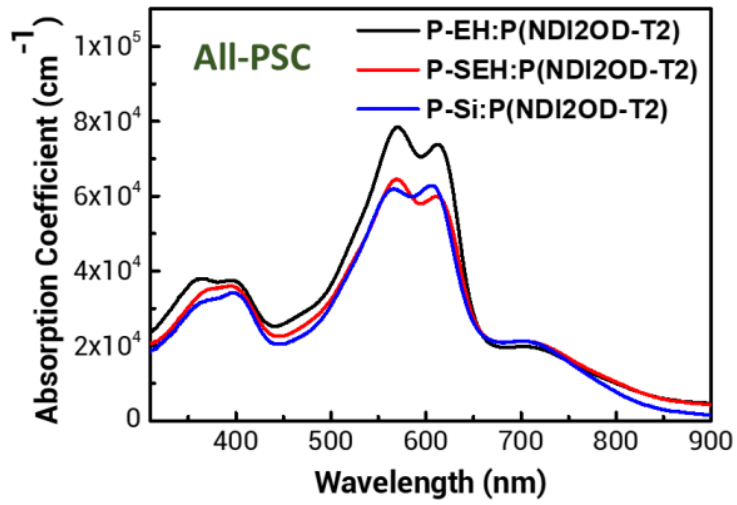

b)

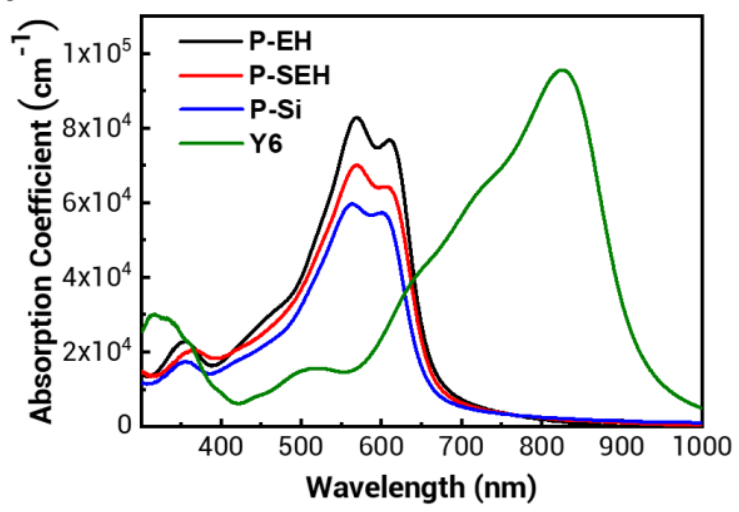

d)

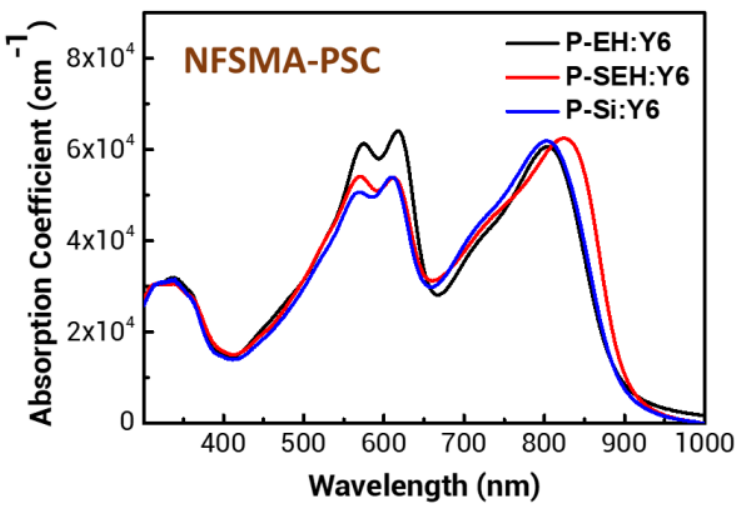

Figure S4. Absorption coefficients of pristine films of $P_{\mathrm{DS}}$ and acceptors prepared from (a) chlorobenzene solution and (b) chloroform solution. Absorption coefficients of (c) $P_{\mathrm{D}}: \mathrm{P}(\mathrm{NDI} 2 \mathrm{OD}-\mathrm{T} 2)$ and (d) $P_{\mathrm{D}}: \mathrm{Y} 6$ blend films at the optimized device condition. 
Table S4. SCLC hole and electron mobilities of all-PSC and NFSMA-PSC blend films.

\begin{tabular}{cccc}
\hline Film & $\begin{array}{c}\mu_{\mathrm{h}}^{\mathrm{a}} \\
\left(\mathrm{cm}^{2} \mathrm{~V}^{-1} \mathrm{~s}^{-1}\right)\end{array}$ & $\begin{array}{c}\mu_{\mathrm{e}}^{\mathrm{a}} \\
\left(\mathrm{cm}^{2} \mathrm{~V}^{-1} \mathrm{~s}^{-1}\right)\end{array}$ & $\mu_{\mathrm{h}} / \mu_{\mathrm{e}}$ \\
\hline P-EH:P(NDI2OD-T2) & $3.8 \times 10^{-4}$ & $1.0 \times 10^{-4}$ & 3.68 \\
P-SEH:P(NDI2OD-T2) & $6.7 \times 10^{-5}$ & $1.4 \times 10^{-4}$ & 0.49 \\
P-Si:P(NDI2OD-T2) & $4.5 \times 10^{-5}$ & $1.2 \times 10^{-4}$ & 0.38 \\
\hdashline P-EH:Y6 & $1.4 \times 10^{-4}$ & $2.4 \times 10^{-4}$ & 0.56 \\
\hline P-SEH:Y6 & $1.0 \times 10^{-4}$ & $1.9 \times 10^{-4}$ & 0.53 \\
P-Si:Y6 & $2.1 \times 10^{-4}$ & $1.7 \times 10^{-4}$ & 1.25 \\
\hline
\end{tabular}

a Average values were obtained from more than 5 devices.

a)

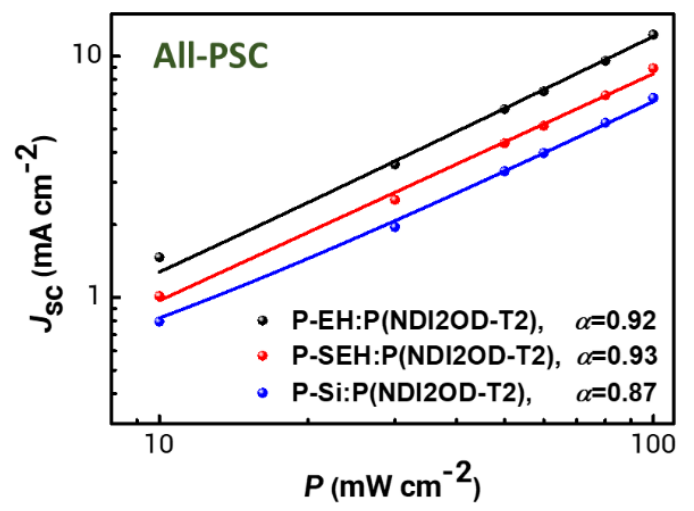

b)

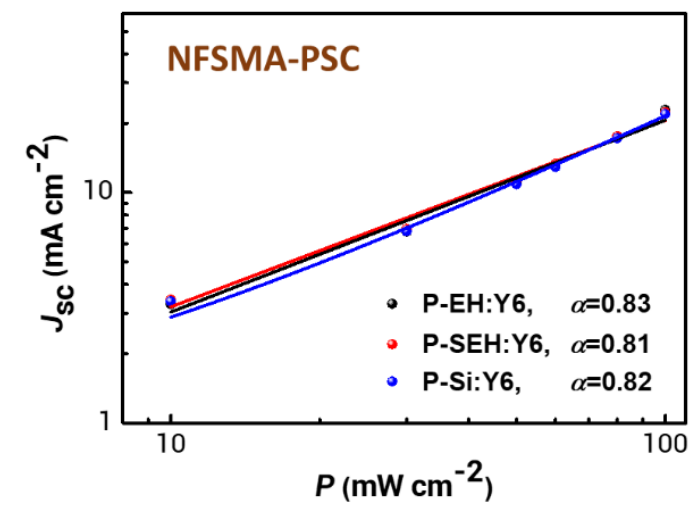

Figure S5. Dependence of $J_{s c}$ on light intensity of (a) $P_{\mathrm{D}}: \mathrm{P}\left(\mathrm{NDI} 2 \mathrm{OD}-\mathrm{T} 2\right.$ ) and (b) $P_{\mathrm{D}}$ :Y6-based PSCs. 
a)

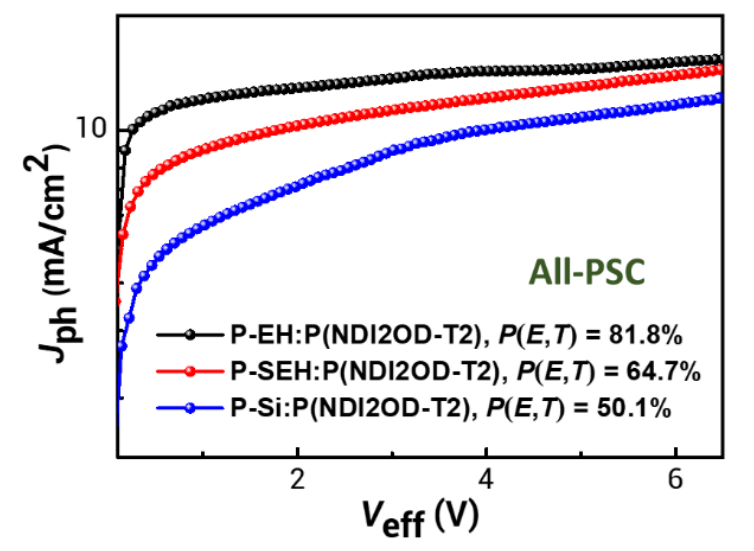

b)

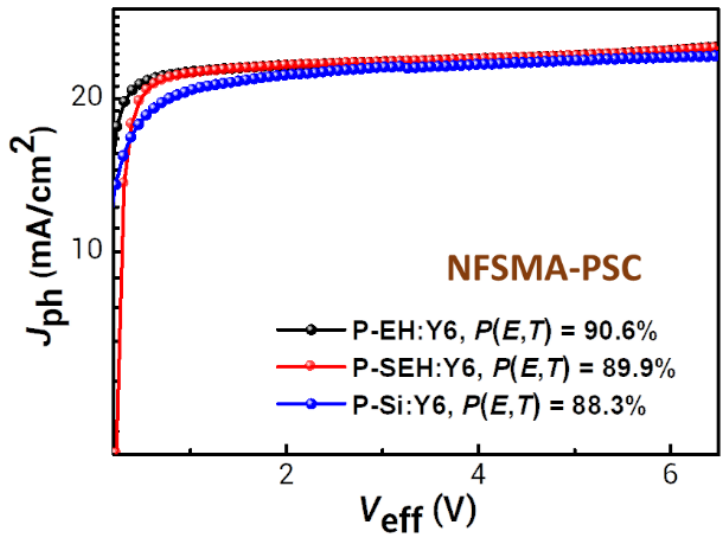

Figure S6. Photocurrent analysis of (a) $P_{\mathrm{D}}: \mathrm{P}(\mathrm{NDI} 2 \mathrm{OD}-\mathrm{T} 2)$ and (b) $P_{\mathrm{D}}:$ Y6-based PSCs.

a)

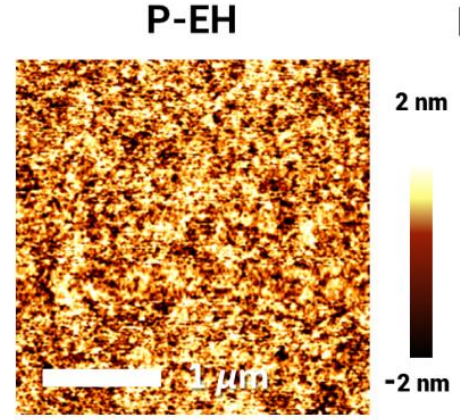

b)

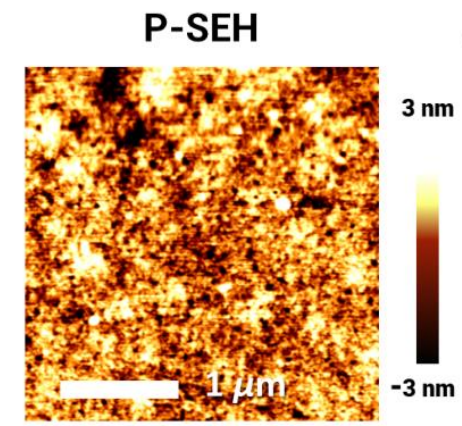

c)

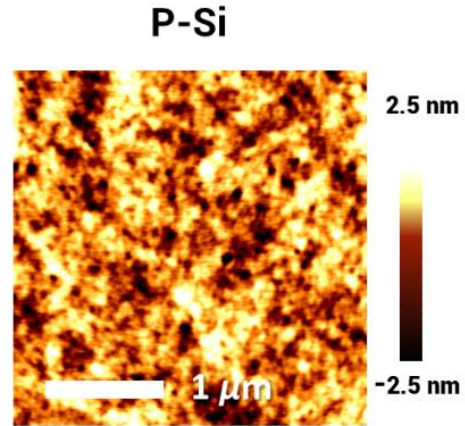

Figure S7. AFM height images measured with pristine films of (a) P-EH, (b) P-SEH, and (c) P-Si. 
a)
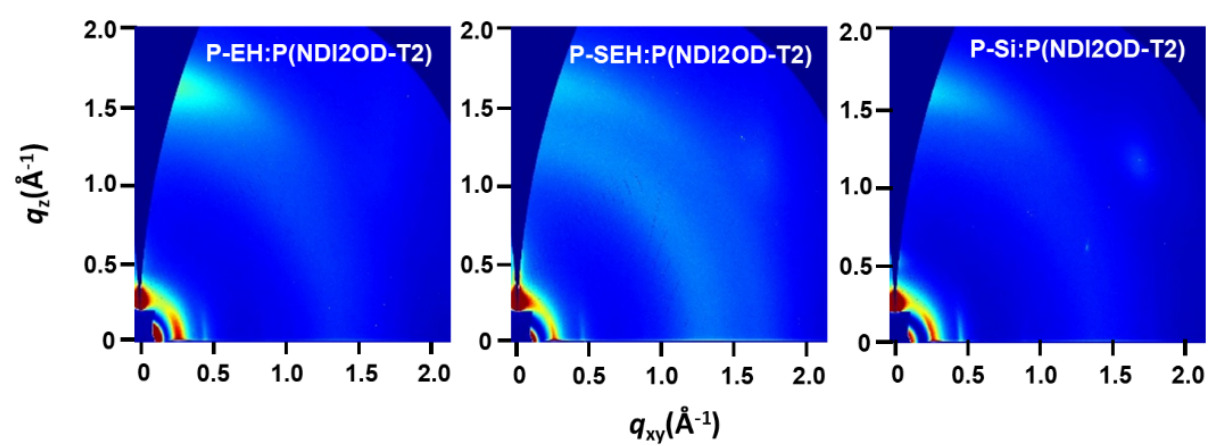

b)
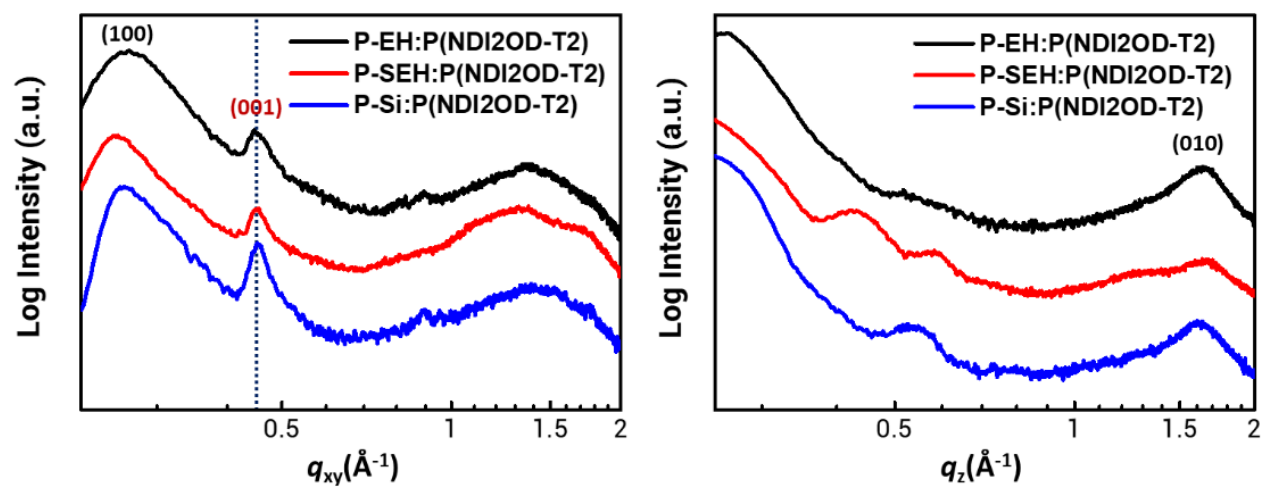

c)
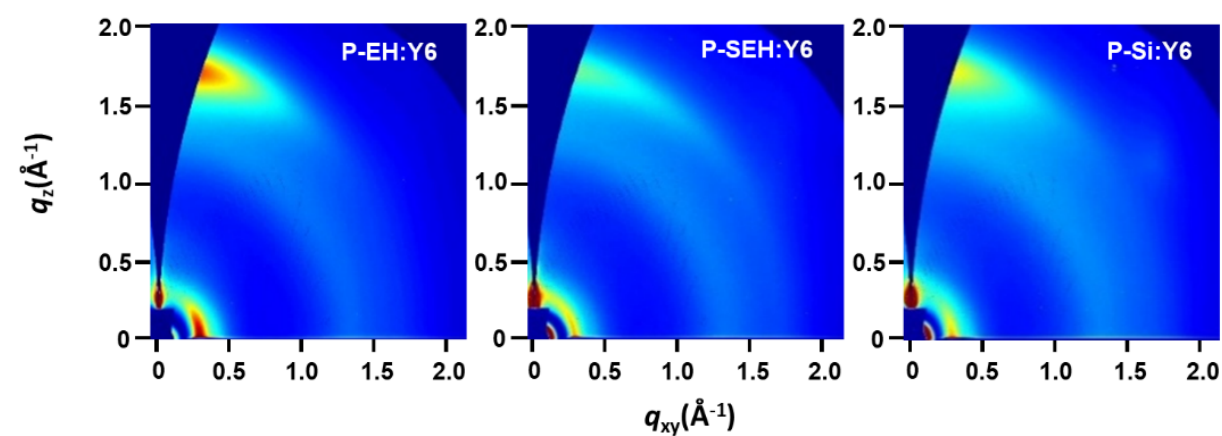

d)
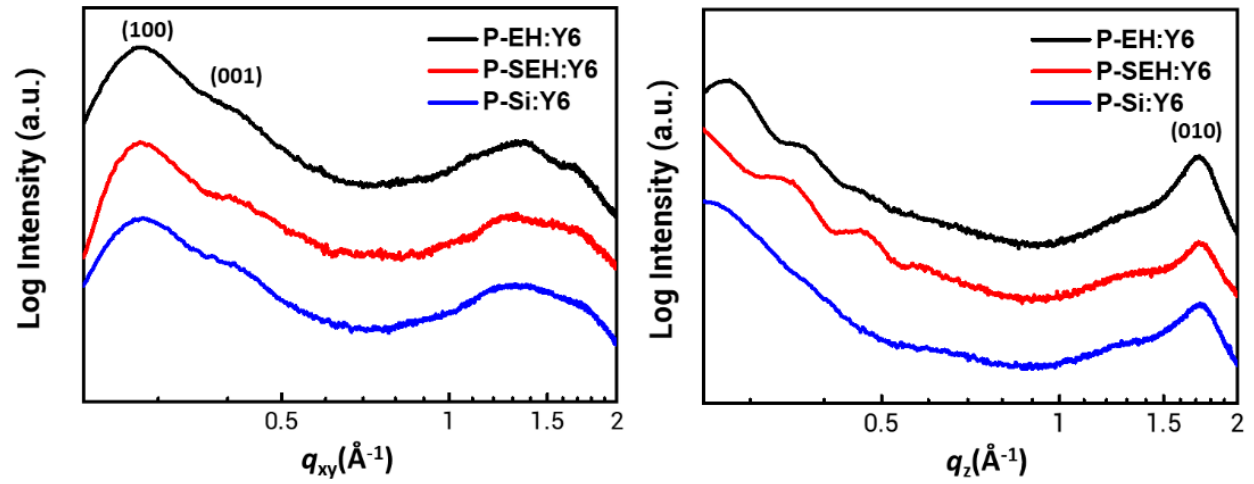

Figure S8. (a) GIXS patterns of all-PSC blend films. (b) In-plane $\left(q_{x y}\right)$ and out-of-plane $\left(q_{z}\right)$ linecuts of GIXS patterns of all-PSC blend films. (c) GIXS patterns of NFSMA-PSC blend films. (d) In-plane $\left(q_{x y}\right)$ and out-of-plane $\left(q_{z}\right)$ linecuts of GIXS patterns of NFSMA-PSC blend films. 
Table S5. Contact angles and surface tensions of $P_{\mathrm{DS}}$ (P-EH, P-SEH, and P-Si), P(NDI2OD$\mathrm{T} 2)$, and Y6 films measured with water and glycerol. Estimated interfacial tensions between $P_{\mathrm{DS}}$ and acceptors (P(NDI2OD-T2) and Y6).

\begin{tabular}{cccccc}
\hline Materials & $\begin{array}{c}\Theta_{\text {water }} \\
(\mathrm{deg})\end{array}$ & $\begin{array}{c}\Theta_{\text {glycerol }} \\
(\mathrm{deg})\end{array}$ & $\begin{array}{c}\text { Surface } \\
\text { tension } \\
\left(\mathrm{mN} \mathrm{m}^{-1}\right)\end{array}$ & $\begin{array}{c}\text { Interfacial } \\
\text { tension } \\
\left(\mathrm{mN} \mathrm{m}^{-1}\right)^{\mathrm{a}}\end{array}$ & $\begin{array}{c}\text { Interfacial } \\
\text { tension } \\
\left(\mathrm{m} \mathrm{N} \mathrm{m}^{-1}\right)^{\mathrm{b}}\end{array}$ \\
\hline P(NDI2OD-T2 $)$ & 96.1 & 85.3 & 24.2 & - & - \\
Y6 & 89.0 & 79.9 & 26.6 & - & - \\
P-EH & 98.2 & 90.0 & 21.4 & 0.61 & 0.61 \\
P-SEH & 99.5 & 92.6 & 20.1 & 1.42 & 0.97 \\
P-Si & 98.4 & 91.6 & 20.6 & 1.51 & 0.87 \\
\hline
\end{tabular}

${ }^{\mathrm{a}}$ Interfacial tension between each $P_{\mathrm{D}}$ and P(NDI2OD-T2). ${ }^{\mathrm{b}}$ Interfacial tension between each $P_{\mathrm{D}}$ and $\mathrm{Y} 6$. 


\section{References}

(1) Kim, J.-H.; Wood, S.; Park, J. B.; Wade, J.; Song, M.; Yoon, S. C.; Jung, I. H.; Kim, J.-S.; Hwang, D.-H. Optimization and Analysis of Conjugated Polymer Side Chains for HighPerformance Organic Photovoltaic Cells. Adv. Funct. Mater. 2016, 26, 1517-1525.

(2) Lee, W.; Lee, C.; Yu, H.; Kim, D.-J.; Wang, C.; Woo, H. Y.; Oh, J. H.; Kim, B. J. Side Chain Optimization of Naphthalenediimide-Bithiophene-Based Polymers to Enhance the Electron Mobility and the Performance in All-Polymer Solar Cells. Adv. Funct. Mater. 2016, 26, 1543-1553. 